Silva, V. A.; Perez Filho, A.; Moreira, V. B.; Lämmle, L.; Torres, B. A.; Ayer, J. E. B.; Spalevic, V.; Mincato, R. L. (2021): Characterization and geochronology of the deltaic system from Jequitinhonha River, Brazil. Agriculture and Forestry, 67 (3): 121-134.

DOI: 10.17707/AgricultForest.67.3.10

Vinícius de Amorim SILVA', Archimedes PEREZ FILHO' ${ }^{2}$, Vinícius Borges MOREIRA ${ }^{2}$, Luca LÄMMLE ${ }^{2}$, Bruno Araujo TORRES ${ }^{2}$, Joaquim Ernesto Bernardes AYER, Velibor SPALEVIC ${ }^{4}$, Ronaldo Luiz MINCATO ${ }^{5}$

\title{
CHARACTERIZATION AND GEOCHRONOLOGY OF THE DELTAIC SYSTEM FROM JEQUITINHONHA RIVER, BRAZIL
}

\section{SUMMARY}

Deltaic systems possess singular morphology and represent a portion of the Brazilian large fluvial systems, with complex dynamics and mouths located at the Atlantic Ocean. Landscapes generated are occupied by diverse human activities over the coast and depend on a certain degree of dynamic equilibrium to its maintenance. The mouth of Jequitinhonha River, located at the extreme South of Bahia state, has suffered great transformations over the last decades, causing coastal erosion processes due to fluvial discharge reduction, thus changing the local dynamic. So, to understand the preterit deltaic dynamic and the possible agents of the current changes, we proposed an approach utilizing grain size and Optically Stimulated Luminescence (OSL) of the deposits by the river mouth, with the processes currently demonstrated. The main results point to mixed depositional environment over the sampling points and additionally in depths, demonstrating cyclicity of depositional agents and energy. Depositional ages obtained were $2.72 \pm 0.23(\mathrm{Ky})$ for the left riverbank, $1.1 \pm 0.15(\mathrm{Ky})$ for the right riverbank, and the youngest deposit located at the front island, with absolute dating of $0.555 \pm 0.065(\mathrm{Ky})$. The results evidence a tendency of coastal progradation during the last thousands of years, prior to anthropic interventions which diminished and regulated fluvial discharge of Jequitinhonha River, resulting in advancement of local coastal erosive processes.

Key words: Deltaic system, Grain size, Coastal erosion, Holocene.

\footnotetext{
${ }^{1}$ Vinícius de Amorim Silva, (correspondence: vinicius@ufsb.edu.br) Technoscience and Innovation Training Center, Federal University of Southern Bahia - UFSB, Itabuna, Bahia, BRAZIL;

${ }^{2}$ Archimedes Perez Filho, Vinícius Borges Moreira, Luca Lämmle, Bruno Araujo Torres, Institute of Geosciences, Department of Geography, State University of Campinas - UNICAMP, Campinas, São Paulo, BRAZIL;

${ }^{3}$ Joaquim Ernesto Bernardes Ayer, Brazilian Agricultural Research Company - EMBRAPA, Jaguariúna, São Paulo, BRAZIL and Paulínia University Center - UNIFACP, Paulínia, São Paulo, BRAZIL;

${ }^{4}$ Velibor Spalevic, University of Montenegro, Biotechnical Faculty, Podgorica, MONTENEGRO;

${ }^{5}$ Ronaldo Luiz Mincato, Institute of Natural Sciences, Federal University of Alfenas, UNIFAL-MG, Alfenas, Minas Gerais, BRAZIL.

Notes: The authors declare that they have no conflicts of interest. Authorship Form signed online. 


\section{INTRODUCTION}

It is becoming acknowledged that water is likely to be the most pressing environmental concern (Aaron et al, 1999). The flow of rivers is part of a greater flow, the planet's water cycle, which sustains not only the flow of water but the entire web of life (Karr \& Chu, 2020). River networks, the backbone of most landscapes on Earth, collect and transport water, sediment, organic matter, and nutrients from upland mountain regions to the other rivers, lakes, seas and oceans (Spalevic et al, 2013.;Willett et al, 2014.; Nikolic et al, 2019.; Chalise et al, 2019.; Spalevic et al, 2020.; Santana et al, 2021.; Tavares et al, 2021).

Large rivers from Brazil are known to develop highly complex deltaic systems over their river mouths in the Atlantic Ocean, due to higher sedimentary load, sediment rework capability by marine processes tend to be lower (Christofoletti, 1981; Suguio, 2003; Rossetti, 2008). Generally, these deltaic systems locally enlarge the coastal plain, causing prominent coast progradation, preserving Quaternary environmental conditions in the Brazilian coast, as described by Martin et al. (1993), thus raising their importance in the paleo environmental context.

According to Goudie (2006) the terminology delta is used from 450 years B.C., cited by Herodotus to describe sandy deposits in triangular shapes located at the mouth of Nile River, resembling the delta letter from Greek alphabet. However, more specific studies within the theme generated important conceptual changes, becoming more generic, increasing the scope related to the term, until reaching complex deltaic systems, comprising, according to Scoot and Ficher (1969), Wright (1978) sedimentary accumulation from fluvial deposits in coastal environments, comprising sub-aqueous, sub-aeolian, and in adjacent or closely related, including secondarily reworked deposits by diverse marine agents; waves, currents, and tides.

Observing Brazilian coastal context, Martin et al. (1993) concluded that a delta encompasses several forms of coastal accumulation in a broad spectrum, containing beach deposits, dunes, tidal flats, swamps, mangroves, lagoons, barrier island, bays, in addition to channel deposits and river mouth. The concept of deltaic systems is used to denominate geomorphological units present in progradation zones, connected to the fluvial system, built originally from sediments carried by rivers that flow towards a permanent body of water in a stillness state. Therefore, the speed of fluvial currents decreases from the contact with the new environment, so the sediments are gradually/selectively deposited, continuously, depending on its mass and morphology, and marine processes posteriorly could rework such material.

The progradation of the coastal line occurs as the contribution from fluvial sediments achieve higher energy over the capability of costal processes to erode them, thus, the sedimentary balance is highlighted in the landscape, generating deltaic patterns accordingly with the interaction between coastal/fluvial and marine processes. In contrast, once there is a sedimentary deficit, the ocean advances over the continent due to decline of material from the river discharge, generating new debris, thus resulting in coastal erosion.

Deltas, due to natural resources availability, especially hydrocarbons, demanded various researches in energy resources, as for its economic relevance, 
these studies focus on prospecting, exploration of mineral coal and petroleum (Suguio, 2003). The knowledge regarding deltaic sedimentation is combined to the deltaic cycle, constituted by constructive and destructive phases. The constructive phase is formed by an active period of intense sediment progradation confined to the distributors in the river mouth, resulting in an abandonment of these distributors, making an extensive sediment progradation. Posteriorly, the destructive phase encompasses deposit rework by active processes in the receptor basin, presenting typical marine features (Coleman and Gagliano, 1965; Scruton, 1960; Suguio, 2003).

From this panorama, the aim of this work is to perceive the preterit and current dynamic of Jequitinhonha River deltaic system, to understand the environment framework through grain size analysis and Optically Stimulated Luminescence (OSL) geochronology of depositional events in the deltaic system, correlating those with local and regional studies. Thus, presenting aggradation tendencies from the Holocene dynamics, in comparison to the current coastal erosive context established in the region, pointing to possible natural and anthropic factors as agents of changes in the deltaic system.

\section{MATERIAL AND METHODS}

Study area. Jequitinhonha River source is located at the Espinhaço ridge, South of Diamantina city, in the state of Minas Gerais, in approximately $1.260 \mathrm{~m}$ high, and its mouth located on the Atlantic Ocean in the municipality of Belmonte, extreme South of Bahia state, Brazil (Figure 1).

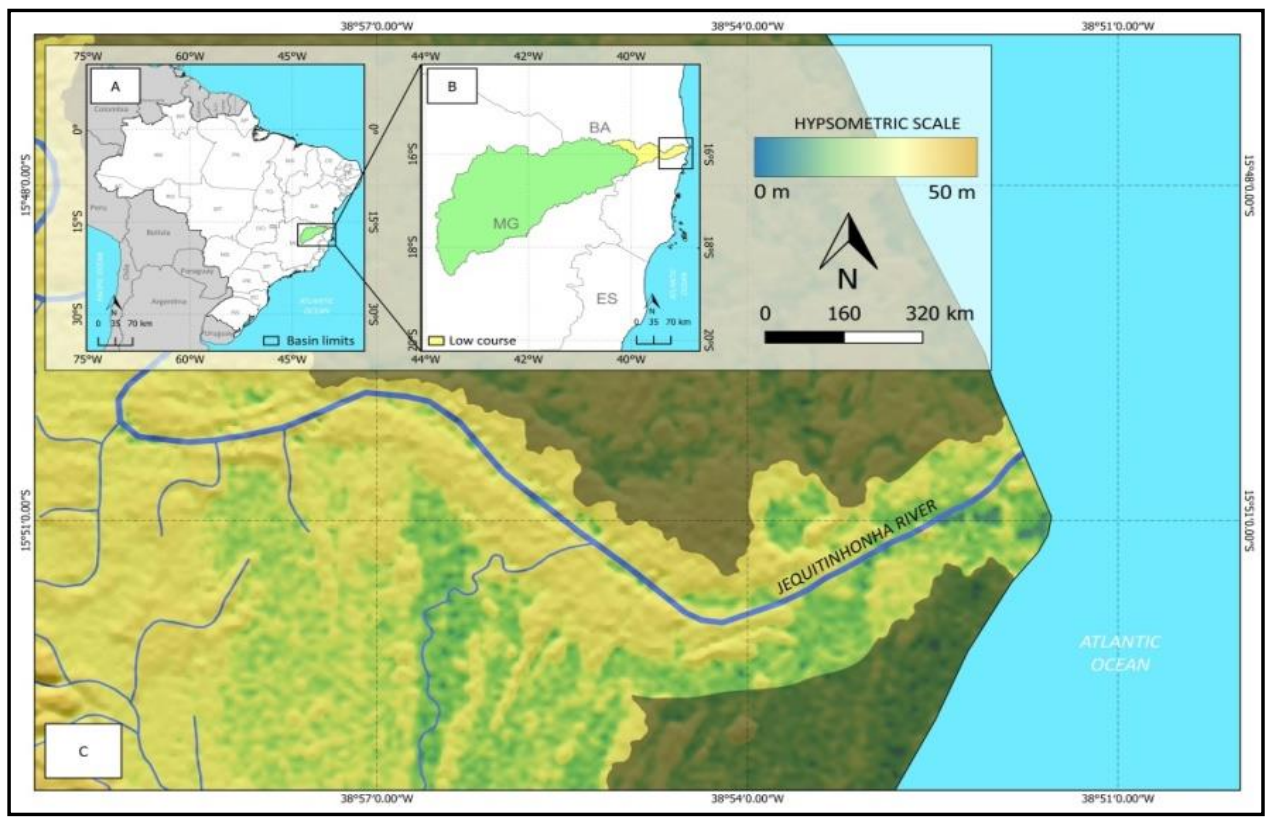

Figure 1. Location of the study area: A) position in Brazil. B) Jequitinhonha River basin and the study area in the low course. C) Study area with the hypsometric scale. The geographic coordinate system is UTM Sirgas 2000. Datum: WGS 84. Source: (ANA, 2016). 
Its drainage basin comprehends a total area of approximately $70.315 \mathrm{~km}^{2}$, and the portion located in Bahia state covers approximately $3.996 \mathrm{~km}^{2}$ (SEI, 2011). The largest portion of Jequitinhonha River basin is located at the Northeast part of Minas Gerais state, with a size of $66.319 \mathrm{~km}^{2}$, equivalent to $93.6 \%$ of its total area, while the smallest area is located at the extreme South of Bahia state, equivalent to $6,4 \%$ of its total area. The Jequitinhonha River basin limits are the following: Pardo River drainage basin to the North; Santo Antônio River drainage basin to the South; São Francisco River drainage basin to the West, trespassing Bahia state limit, entering Minas Gerais state; Atlantic Ocean to the East, (SEI, 2004).

The lithostratigraphic units from Jequitinhonha River are highly heterogeneous, encompassing diverse geological Groups and Formations, due to its large territorial extension. However, as this research focuses in the coastal plain, specifically the deltaic system, Barreiras Group is considered the base lithology to structure the coastal plateau relief in the Southern region of Bahia, representing the coastal plain inner boundary with distinct distances to the ocean. According to Araújo et al. (2006) Barreiras Group consists in the most expressive geological unit from Brazil, occurring from the North of Rio de Janeiro state to the state of Amapá, along with part of Brazilian coast, presenting sediments with variable grain size from Miocene.

Past Barreiras Group consolidation in Bahia Southern region, the Group was eroded and reworked by marine and fluvial processes during the Quaternary, constituting part of the available sediments along the coastal plain, arriving at the present geomorphological aspects, according to evolutive model proposed by Arai (2006) in a series of papers about the theme. In mapping performed by CPRM (2006) five (5) sedimentary deposits are highlighted at Southern Bahia coastal plain, these deposits possess diverse origins, related to marine transgressive and regressive moments, alluvial debts, lagoon deposits, and Barreiras Group rework establishing the core of the deltaic environment.

According to the map of land use and land cover elaborated by Silva (2012) the native vegetation consists of restingas over the coastal plain and diverse Atlantic Forest phitophsiognomies over the coastal plateau and valley bottom. The region has been historically used by production of cocoa and livestock, however over the last decades; forestry occupies large areas, replacing older crops, due to pulp industry installation in the region, demanding such feedstock. Another important land use in the region is Itapebi hydroelectric power station, located in the low course of Jequitinhonha River, causing negative effects to channel flow regularization and dynamics, discussed by Silva (2012), elaborating important parameter to the discussions of this work.

Nascimento et al. (2007) correlates geomorphological continental processes with marine processes to explain the predominant direction SouthNorth from the longshore drift present in the extreme South of Bahia, inferring that higher intensity is related to the large input of solid particulate material carried by the large Jequitinhonha and Pardo Rivers, originating the coastal plain 
largest portion over the last thousands of years, thus creating the complex deltaic system analyzed. Lastly, another relevant characteristic observed at the study area consists in the connectivity in between the diverse drainage basins in the region, mainly among Jequitinhonha and Pardo Rivers, possessing secondary channels connecting both basins, generating certain complexity degree in their delimitation. Drainage catchments with current features are commonly found in plain and low areas over the coastal plain, where the same channel distributes water to two distinct sub-basins, exhibiting wide influence as tide ebb and flow, floods, and droughts.

Methods. Before methodological procedures, there is an importance to highlight marine terraces and delta from Jequitinhonha River as component of landscape surficial covers, described by Perez Filho and Rubira (2019). These elements are potential geomorphological indicators of environmental changes, directly associated to variations in the deltaic dynamics, thus surficial covers are the discussed and dated object within the analyzed system.

The OSL technique was chosen to obtain absolute dating data from the material composing surficial covers, due to its analytic characteristics encompassing the main hypothesis from surficial covers genesis. Therefore, during the material transport, diagnostic materials (Feldspar and Quartz), were exposed to solar radiation during enough time to reset stored luminescence and posteriorly deposited, starting new environment radiation absorption as described by Sallun et al (2007).

The sampling for OSL dating was carried out with all the necessary care to avoid sample direct contact with sunlight, as recommended by the laboratory responsible for processing the samples. To collect a sample, a $60 \mathrm{~cm}$ length and 6 $\mathrm{cm}$ diameter PVC tube (Polyvinyl chloride) was used, properly packaged after removed from the deposit until taken to laboratory for analysis. The sampling depths vary between 70 and $80 \mathrm{~cm}$, contemplating homogenous material with apparent sandy texture.

At the laboratory Datação LTDA, the OSL samples were analyzed utilizing the SAR - Single Aliquot Regenerative protocol, described by Wintle and Murray $(2000,2006)$ where 15 repetition aliquots were carried out for each sample. Alongside OSL sampling, grain size samples were collected in different depths to identify texture changes within the deposit. Posterior to the sampling procedure, the samples were sent to the soil laboratory of Agriculture Faculty (FEAGRI - UNICAMP), where grain size analysis was performed, sorting five fractions of sand, clay, and silt by sieving and pipette methods, described by Camargo et al. (1986) and EMBRAPA (1997).

After measuring particle size, a statistic analysis was performed. The free source software Sysgran 3.0 was used (Camargo, 2006). Among the data generated by the software, statistical parameters were average, median, selection, asymmetry, and kurtosis with method develop by Folk \& Ward (1957). Cumulative frequency graphics of the fraction in each sampling point were generated utilizing the same software. 


\section{RESULTS AND DISCUSSION}

We have selected 3 collection points in the study area to apply the described methodology, located at the left and right riverbank and the front island of Jequitinhonha River, according to figure 2 found by the river mouth, and these points represent the current deltaic system dynamics.

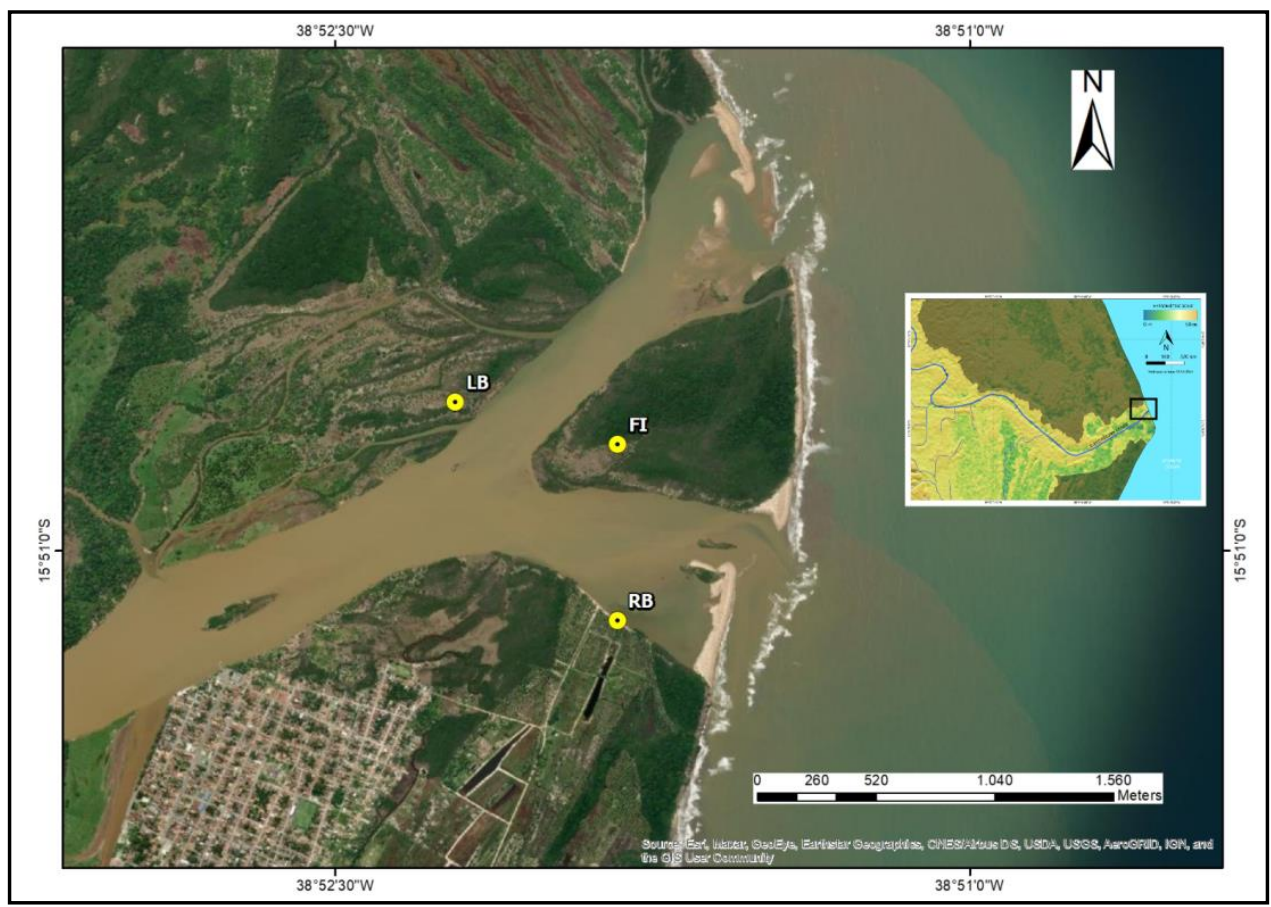

Figure 2 - Sampling points location by the mouth of Jequitinhonha River. LB - Left Riverbank; RB - Right Riverbank; FI - Front Island. Source: (ANA, 2016, IBGE, 2015).

Grain size analysis performed to characterize the surficial covers present at the study area represent the dynamism of this deltaic system located at the river mouth, for the analyzed fraction vary significantly along the selected points as per depths. Grain size cumulative frequency curves (figure 3) enlighten the difference between samples, as the cumulative patterns diverge, evidencing influence of distinct genetic agents in the construction of sedimentary deposits.

At the right riverbank it was possible to notice higher presence of thinner fractions as depth increases, this point also presented higher variation of gran size fractions in higher depths, indicating multiple transport agents and variable energy during the deposit genesis, possibly connected to fluvial discharge oscillation within the area. The left riverbank presented a distinct behaviour, pointing to distinct deposition dynamics over the study area.

Thicker fractions had a bigger presence on surficial layers in contrast to deeper ones on the right riverbank deposit, clearly indicating a higher energy dynamic over the genesis of youngest layer. Whilst the left riverbank presented lower variation in the parameters analyzed with closer cumulative frequency 
curves and a lack of muddy material. Therefore, higher concentration of thicker sand fractions in left riverbank, indicate more energetic environment and/or influence of marine deposits over this deposit.

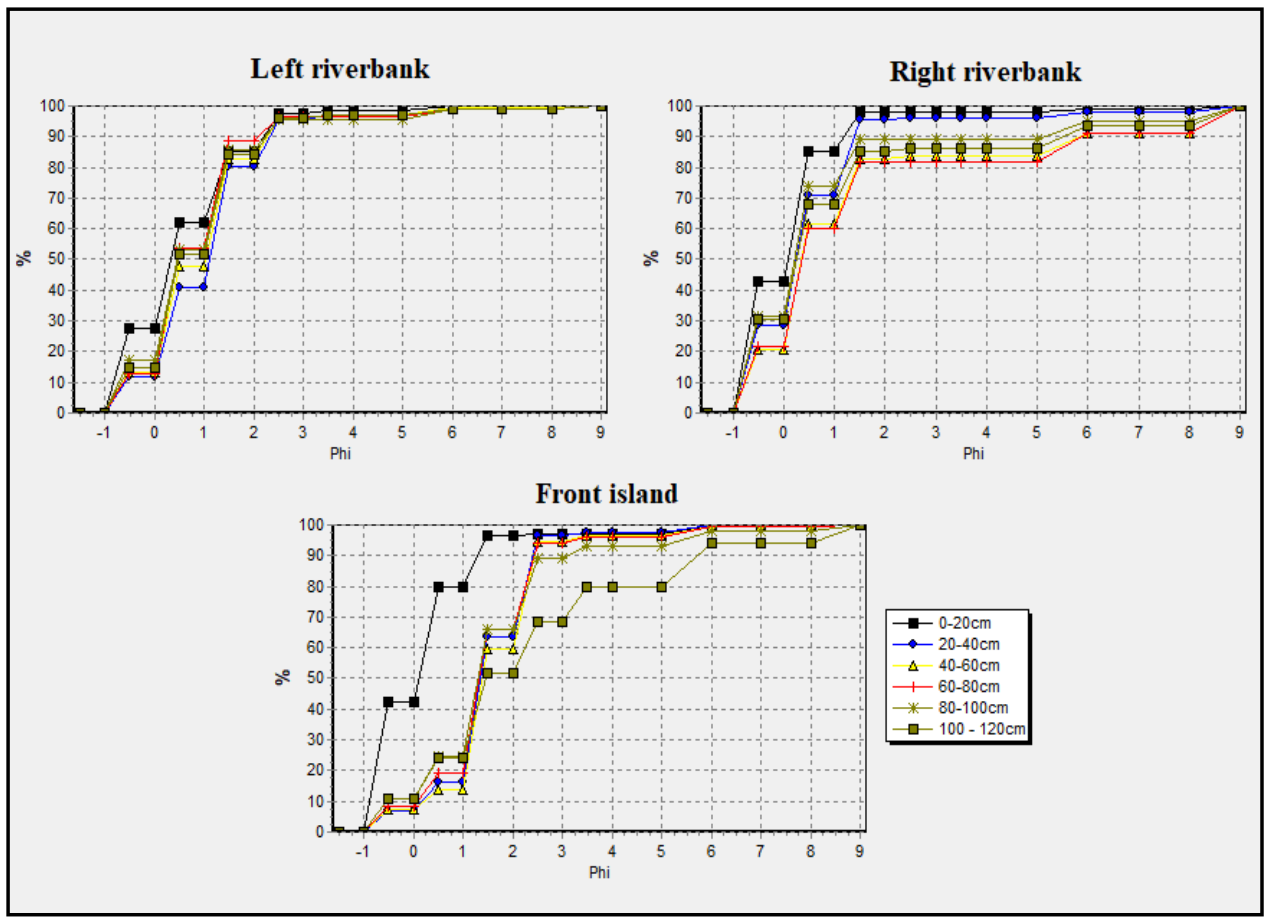

Figure 3 - Grain size cumulative frequency curves in Phi scale. (Sysgran 3.0.)

We have performed grain size analysis following the statistic and descriptive method from Folk and Ward (1957) which is presented in table 1. These parameters emphasize observations previously made, demonstrating heterogeneity within the deposits. Regarding mean classification, modal fraction varied between very coarse, coarse, and medium sand, material commonly deposited in fluvio-marine environments.

According to Martins (2003), material selection measured by grain size analysis could be an indicative of the agent involved in transporting the sedimentary material, related to beach deposits moderate selection, comparatively to poorly selected related to fluvial transport. Thus, we observed processes intercalation, both in depths and sampled points, indicating non prevalence of a unique process in each of the points.

Asymmetry parameter is another important factor to observe in table 1, for positive asymmetry is generally associated to beach deposits, whereas negative asymmetry is linked to fluvial deposits, complementing the selection parameter analysis according to Martins (2003). We observed that not all analyzed deposits achieve the described combination, possibly due to influence of a mixed environment, where presented parameters are crossed, thus complicating a clear interpretation. 
Table 1. Grain size statistic parameters by Folk and Ward (1975)

\begin{tabular}{|c|c|c|c|c|c|c|c|c|}
\hline \multicolumn{9}{|c|}{ Left riverbank } \\
\hline $\begin{array}{c}\text { Depth } \\
\mathrm{cm}\end{array}$ & Class. & Median & \multicolumn{2}{|c|}{ Selection } & \multicolumn{2}{|c|}{ Asymmetry } & \multicolumn{2}{|c|}{ Kurtosis } \\
\hline $0-20$ & $\begin{array}{c}\text { Coarse } \\
\text { sand }\end{array}$ & 0,3266 & 1,048 & $\begin{array}{l}\text { Poorly } \\
\text { selected }\end{array}$ & 0,1532 & Positive & 0,7435 & Platykurtic \\
\hline $20-40$ & $\begin{array}{l}\text { Medium } \\
\text { sand }\end{array}$ & 1,115 & 1,01 & $\begin{array}{c}\text { Poorly } \\
\text { selected }\end{array}$ & $\begin{array}{c}- \\
0,0909\end{array}$ & $\begin{array}{c}\text { Approx. } \\
\text { symmetric }\end{array}$ & 1,11 & Mesokurtic \\
\hline $40-60$ & $\begin{array}{l}\text { Medium } \\
\text { sand }\end{array}$ & 1,029 & 0,999 & $\begin{array}{c}\text { Moderately } \\
\text { selected }\end{array}$ & $\begin{array}{c}- \\
0,0550\end{array}$ & $\begin{array}{c}\text { Approx. } \\
\text { symmetric }\end{array}$ & 1,097 & Mesokurtic \\
\hline $60-80$ & $\begin{array}{c}\text { Coarse } \\
\text { sand }\end{array}$ & 0,4535 & 0,834 & $\begin{array}{c}\text { Moderately } \\
\text { selected }\end{array}$ & 0,3087 & Very positive & 1,134 & Leptokurtic \\
\hline $\begin{array}{l}80- \\
100\end{array}$ & $\begin{array}{c}\text { Coarse } \\
\text { sand }\end{array}$ & 0,4567 & 1,005 & $\begin{array}{c}\text { Poorly } \\
\text { selected }\end{array}$ & 0,11 & Positive & 1,106 & Mesokurtic \\
\hline $\begin{array}{l}100- \\
120\end{array}$ & $\begin{array}{c}\text { Coarse } \\
\text { sand }\end{array}$ & 0,4783 & 0,868 & $\begin{array}{c}\text { Moderately } \\
\text { selected }\end{array}$ & 0,2898 & Positive & 1,102 & Mesokurtic \\
\hline
\end{tabular}

\begin{tabular}{|c|c|c|c|c|c|c|c|c|}
\hline \multicolumn{9}{|c|}{ Front island } \\
\hline Depth & Class. & Median & \multicolumn{2}{|c|}{ Selection } & \multicolumn{2}{|c|}{ Asymmetry } & \multicolumn{2}{|c|}{ Kurtosis } \\
\hline $0-20$ & $\begin{array}{l}\text { Very } \\
\text { coarse } \\
\text { sand }\end{array}$ & 0,0835 & 0,676 & $\begin{array}{c}\text { Moderately } \\
\text { selected }\end{array}$ & $-0,1324$ & Negative & 0,877 & Platykurtic \\
\hline $20-40$ & $\begin{array}{c}\text { Coarse } \\
\text { sand }\end{array}$ & 0,2524 & 0,860 & $\begin{array}{c}\text { Moderately } \\
\text { selected }\end{array}$ & 0,02516 & $\begin{array}{c}\text { Approx. } \\
\text { symmetric }\end{array}$ & 0,597 & $\begin{array}{c}\text { Very } \\
\text { platykurtic }\end{array}$ \\
\hline $40-60$ & $\begin{array}{l}\text { Medium } \\
\text { sand }\end{array}$ & 0,3564 & 2,83 & $\begin{array}{c}\text { Very } \\
\text { poorly } \\
\text { selected }\end{array}$ & 0,6965 & Very positive & 3,024 & $\begin{array}{l}\text { Extremely } \\
\text { leptokurtic }\end{array}$ \\
\hline $60-80$ & $\begin{array}{l}\text { Medium } \\
\text { sand }\end{array}$ & 0,3669 & 2,875 & $\begin{array}{c}\text { Very } \\
\text { poorly } \\
\text { selected }\end{array}$ & 0,6954 & Very positive & 2,951 & $\begin{array}{c}\text { Very } \\
\text { leptokurtic }\end{array}$ \\
\hline $\begin{array}{l}80- \\
100\end{array}$ & $\begin{array}{c}\text { Coarse } \\
\text { sand }\end{array}$ & 0,2185 & 1,567 & $\begin{array}{c}\text { Moderately } \\
\text { selected }\end{array}$ & 0,3701 & Very positive & 1,723 & $\begin{array}{c}\text { Very } \\
\text { leptokurtic }\end{array}$ \\
\hline
\end{tabular}

\begin{tabular}{|c|c|c|c|c|c|c|c|c|}
\hline \multicolumn{10}{|c|}{ Right riverbank } \\
\hline Depth & Class. & Median & \multicolumn{2}{|c|}{ Selection } & \multicolumn{2}{|c|}{ Asymmetry } & \multicolumn{2}{|c|}{ Kurtosis } \\
\hline $0-20$ & $\begin{array}{c}\text { Coarse } \\
\text { sand }\end{array}$ & 0,1011 & $\begin{array}{c}0,845 \\
5\end{array}$ & $\begin{array}{c}\text { Moderately } \\
\text { selected }\end{array}$ & 0,0922 & $\begin{array}{c}\text { Approx. } \\
\text { symmetric }\end{array}$ & 0,8612 & Platykurtic \\
\hline $20-40$ & $\begin{array}{c}\text { Medium } \\
\text { sand }\end{array}$ & 1,356 & $\begin{array}{c}0,931 \\
4\end{array}$ & $\begin{array}{c}\text { Moderately } \\
\text { selected }\end{array}$ & $-0,1203$ & Negative & 1,184 & Leptokurtic \\
\hline $40-60$ & $\begin{array}{c}\text { Medium } \\
\text { sand }\end{array}$ & 1,393 & $\begin{array}{c}0,898 \\
9\end{array}$ & $\begin{array}{c}\text { Moderately } \\
\text { selected }\end{array}$ & 0,1712 & Positive & 1,402 & Leptokurtic \\
\hline $60-80$ & $\begin{array}{c}\text { Medium } \\
\text { sand }\end{array}$ & 1,329 & 1,092 & $\begin{array}{c}\text { Poorly } \\
\text { selected }\end{array}$ & 0,01297 & $\begin{array}{c}\text { Approx. } \\
\text { symmetric }\end{array}$ & 1,468 & Leptokurtic \\
\hline $80-$ & $\begin{array}{c}\text { Medium } \\
\text { sand }\end{array}$ & 1,307 & 1,483 & $\begin{array}{c}\text { Poorly } \\
\text { selected }\end{array}$ & 0,1525 & Positive & 2,121 & $\begin{array}{c}\text { Very } \\
\text { leptokurtic }\end{array}$ \\
\hline $100-$ & Fine \\
120 & sand & 1,466 & 2,621 & $\begin{array}{c}\text { Very } \\
\text { poorly } \\
\text { selected }\end{array}$ & 0,4984 & Very positive & 1,607 & $\begin{array}{c}\text { Very } \\
\text { leptokurtic }\end{array}$ \\
\hline
\end{tabular}

Source: Sysgran 3.0. 
OSL dating analysis, table 2, provided data to identify distinct depositional events in relation to surficial covers genesis on the banks of Jequitinhonha River and front island. Therefore, the left riverbank was identified as the eldest with $2.72 \pm 0.23(\mathrm{Ky})$, followed by the right riverbank with $1.1 \pm 0.15(\mathrm{Ky})$, and the most recent deposits found within the front island, presenting absolute dating of $0.555 \pm 0.065(\mathrm{Ky})$. The data indicate an heterogenous dynamic in relation to the sampling points, corroborating data obtained from grain size analysis, pointing to distinct depositional events, suggesting channel preferential migration to the right over the last 1000 years B.P., furthermore, the front island presented most recent depositional events, relative to the last 500 years B.P. Similar depositional ages were found by Rocha et al. (2019), by the Paraíba do Sul River, demonstrating correlation between the processes analyzed.

Table 2. Parameters used to measure OSL dating.

\begin{tabular}{|c|c|c|c|c|c|c|c|c|c|c|}
\hline 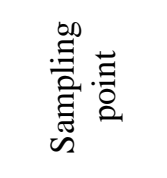 & 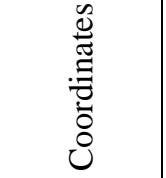 & 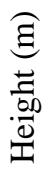 & 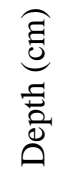 & Е્ત્ત & 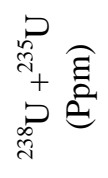 & $\frac{a}{a}$ & 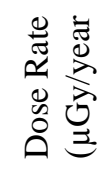 & $\frac{n}{0}$ & - $\widehat{\hat{0}}$ & $\stackrel{\mathscr{U}}{\stackrel{\Xi}{*}}$ \\
\hline $\begin{array}{c}\text { Left } \\
\text { riverbank }\end{array}$ & $\begin{array}{c}15^{\circ} 50^{\prime} 39^{\prime \prime S} \\
38^{\circ} 52^{\prime} 13^{\prime \prime} \mathrm{W}\end{array}$ & 3 & 0,8 & $\begin{array}{r}19,070 \\
\pm 0,687\end{array}$ & $\begin{array}{l}6,731 \\
\pm 0,04\end{array}$ & $\begin{array}{l}0,493 \\
\pm 0,07\end{array}$ & $\begin{array}{l}3.675 \\
\pm 135\end{array}$ & 15 & 10,0 & $\begin{array}{c}2.72 \pm \\
0.23\end{array}$ \\
\hline $\begin{array}{c}\text { Right } \\
\text { riverbank }\end{array}$ & $\begin{array}{r}15^{\circ} 51^{\prime} 10^{\prime \prime S} \\
38^{\circ} 51^{\prime} 50^{\prime \prime} \mathrm{W}\end{array}$ & 4 & 0,8 & $\begin{array}{r}12,110 \\
\pm 0,436\end{array}$ & $\begin{array}{c}3,325 \pm \\
0,27\end{array}$ & $\begin{array}{c}0,943 \pm \\
0,13\end{array}$ & $\begin{array}{c}2.760 \pm \\
245\end{array}$ & 15 & 3,0 & $\begin{array}{l}1.1 \pm \\
0.15\end{array}$ \\
\hline Front island & $\begin{array}{c}15^{\circ} 50^{\prime} 45 " \mathrm{~S} \\
38^{\circ} 51^{\prime} 50^{\prime \prime} \mathrm{W}\end{array}$ & 6 & 0,7 & $\begin{array}{r}18,490 \\
\pm 0,666\end{array}$ & $\begin{array}{c}5,256 \pm \\
0,20\end{array}$ & $\begin{array}{c}0,955 \pm \\
0,13\end{array}$ & $\begin{array}{c}3.600 \pm \\
245\end{array}$ & 15 & 2,0 & $\begin{array}{c}0.555 \pm \\
0.065\end{array}$ \\
\hline
\end{tabular}

Source: Original.

Fluvial discharge and mean sea level oscillations during the Holocene and specially during the Late Holocene is an asset to explain the depositional ages from deposits close to the river mouth obtained through OSL analysis, as they are directly related to the construction and enlargement of the local coastal plain cyclically in different moments. Classic models representing mean sea level oscillations over the Brazilian and South American vast coastline consists in important point for the discussion, although not concordant between one another, the models present general tendencies of the processes investigated in this work, given that these are local variables when considering the dimension and diversity of the Brazilian coast.

So, models elaborated by Suguio et al. (1985), Tomazelli (1990), Coen et al. (2005), Rull et al. (1999), Martin et al. (2003), Angulo et al. (2006), Alves and Rossetti (2017) present the main fluctuations of mean sea level over the last 8 thousand yeas B.P., displaying clear regressive tendency in all periods evaluated, with presence of short-term transgressions over the last 5 thousand years B.P. Therefore, the natural tendency presented is the progradation during great part of the Holocene, particularly during the Late Holocene, period corresponding to the absolute dating obtained. 
Discussing marine influence over fluvial systems and the formation of paleo-mangroves in the Southern coast of Pernambuco and Southern region of Bahia (Fontes et al. 2017, Cohen et al. 2019, Lorente et al. 2020, Martins et al. 2020), describe relevant climate events occurred during the Middle and Late Holocene, pointing to possible raise in mean sea level during 7,400 and 5,350 years A.P., due to presence of palynologic records in intra-continent estuarine systems, currently located until $34 \mathrm{~km}$ from the actual coastline.

Climatic conditions of lower humidity could be the agent responsible to generate marine influence advancement peak (5,350 years A.P.), thus confirming classic models. Fontes et al. (2017) points to a continuous and regressive tendency of mean sea level, strongly influenced by an increment in fluvial discharge from Jucuruçu River in Southern Bahia, caused by higher humidity available during the last thousands of years. Therefore, thus tendency is probably suggested to Jequitinhonha River during the same period.

Contrary to the natural tendencies previously described, in the last decades, we observed an inversion in the dynamics presented in Jequitinhonha River mouth, which is suffering severe fluvial and marine erosion as observed in fieldwork, figure 4, performed in the study area.
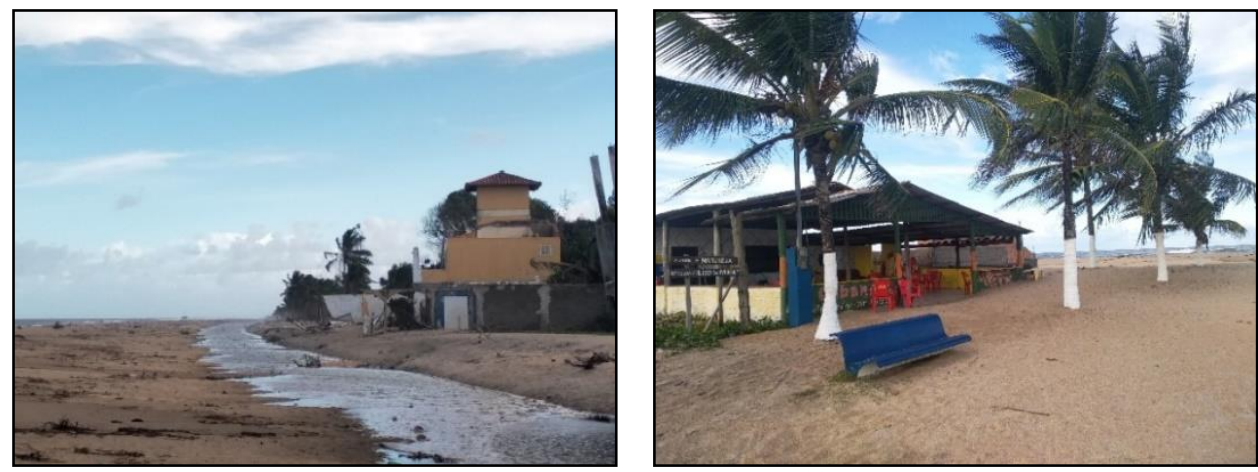

Figure 4 - Houses and commercial establishments new the mouth of Jequitinhonha River under risk due to marine erosion advancement.

Once processes occurring in the coastline of Bahia state were described by Dominguez et al. (2012), there was a highlight to mean sea level rise in the last decades, important variable in this context, however it should be avoided to understand erosion processes in the Brazilian coast, as the variable confuses the comprehension of particular and regional events. Therefore, the main processes related to the dynamics of river mouths that might cause erosion are channel lateral migration in case of small water courses, shifts in mouth bar configuration and natural oscillations of solid and liquid flow. Cases of severe erosion could be associated to anthropic interventions as the construction of ports and sediment bars in river, thus unbalancing the deltaic system.

Observations made by Dominguez et al. (2012) are corroborated by Silva (2012) when performing temporal analysis of orbital and non-orbital historical 
series of images prior to and post Itapebi hydro electrical power plant installation in the low course of Jequitinhonha River, demonstrating the changes observed in the channel layout and in the front island, which decreases in size over the last decades. According to Silva (2012), channel flow regularization caused by the hydroelectric enterprise brought important upstream modifications, promoting channel enlargement, which currently decreased energy, and in the front of river mouth, suffers from the advancement of marine processes.

Strength loss in fluvial discharge has been modifying the entire coastline dynamic, which is also under an erosion moment, particularly on Jequitinhonha River right bank. Regarding the river channel, there is a notable increase in sandbanks and fluvial islands, formed due to the current low transport energy, creating difficulties in boats navigability, and reducing human traditional activities, directly impacting communities residing in this location.

\section{CONCLUSIONS}

Evidences from the past and present are important assets to comprehend the diverse variables that might influence the dynamics of complex deltaic systems and might aid in future impacts mitigation facing the current scenario of global environmental changes. Therefore, through methodology applied, it was possible to identify a natural progradation tendency, which intensified during Late Holocene and nowadays is under transformation at the mouth of Jequitinhonha River, considering that marine processes are causing coastline erosion, thus harming several human activities stablished at the location.

OSL dating demonstrate that all surficial covers close to the mouth of Jequitinhonha River was formed in the last 2000 years B.P., elaborated by several cycles of greater and lesser energy in the deltaic system, with mixed fluviomarine contribution, inferred by grain size analysis, with the front island as the most recent in relation to the riverbanks, which also present an evidenced temporal lapse between one another, indicating preferential migration to the right. These results point to cyclicity within the deltaic system in natural condition, with progradation tendency.

Dynamic equilibrium observed during Late Holocene was disturbed by fluvial discharge reduction and regularization due to hydro electrical enterprise installation upstream, occasioning new hydrodynamic conditions to the system, where marine processes are superimposing fluvial processes, thus eroding the current coastline. In case this new dynamic is maintained, the deltaic system could even disappear, originating a new estuarine system, implying in large local changes, which might reverberate regionally, transforming the geosystemic dynamic in several hierarchic levels.

\section{ACKNOWLEDGEMENTS}

The authors acknowledge CAPES, CNPq and FAPESP for financial support and the Geoscience Institute from Unicamp for institutional support. 


\section{REFERENCES}

Aaron T. Wolf; Jeffrey A. Natharius; Jeffrey J. Danielson; Brian S. Ward \& Jan K. Pender (1999): International River Basins of the World, International Journal of Water Resources Development, 15:4, 387-427, DOI: 10.1080/07900629948682

Alves, F. C. \& Rossetti, D. F. (2017): Late Holocene coastal dynamics and relative sealevel changes in the littoral of Paraíba, north-eastern Brazil. Progress in the Physical Geography: Earth and Environment. 41 (4): 375-392.

ANA - Agência Nacional das Águas (2019): Bacias Hidrográficas do Atlântico Sul Trecho Leste. Bahia, BH7 - Bacia hidrográfica do rio Jequitinhonha. 2016. Série: Sistema Nacional de Informações sobre Recursos Hídricos. CD n 4. Available in: www.hidroweb.ana.gov.br.

Angulo, R. J.; Gguilherme C. Lessa, G. C.; Souza, M. C. (2006): A critical review of midto late-Holocene sea-level fluctuations on the eastern Brazilian coastline. Quaternary Science Reviews. 25: 486-506.

Arai, M. A. (2006): Grande Elevação Eustática do Mioceno e sua Influência na origem do Grupo Barreiras. Revista do Instituto de Geociências. Geol. USP Sér. Cient.; 6 (2): 1-6.

Araújo, V.D.; Reyes-perez, Y.A.; Lima, R.O.; Pelosi, A.P.M.R.; Menezes, L.; Córdoba, V.C.; Lima-Filho, F.P. (2006): Fácies e Sistema Deposicional da Formação Barreiras na Região da Barreira do Inferno, Litoral Oriental do Rio Grande do Norte. Revista do Instituto de Geociências. São Paulo, 6(2): 43-49.

Camargo, M.G. (2006): Sysgran: um sistema de código aberto para análises granulométricas do sedimento. Revista Brasileira de Geociências, 36 (2): 371-378.

Camargo, O.A.; Moniz, A.C.; Jorge, J.A. \& Valadares, J.M. (1986): Métodos de análise química, mineralógica e física de solos do Instituto Agronômico de Campinas. Campinas: Instituto Agronômico de Campinas, (IAC-Boletim Técnico, 106), 94p.

Chalise, D.; Kumar, L.; Spalevic, V.; Skataric, G. (2019): Estimation of Sediment Yield and Maximum Outflow Using the IntErO Model in the Sarada River Basin of Nepal. Water 2019, 11: 952. https://doi.org/10.3390/w11050952

Christofoletti, A. (1981): Geomorfologia Fluvial. São Paulo: Edgard Blücher. 312p.

Cohen, M. C. L.; Behling, H.; Lara, R. J. (2005): Amazonian mangrove dynamics during the last millennium: The relative sea-level and the little ice age. Review of Palaeobotany and Palynology. 136: 93-108.

Cohen, M.C.L.; Figueiredo, B.L.; Oliveira, N.N.; Fontes, N.A.; França, M.C.; Pessenda, L.C.R.; Souza, A.V.; Mmacario, K.; Giannini, P.F.C.; Bendassolli, J.A.; Lima, P.N. (2019): Impacts of Holocene and modern sea-level changes on estuarine mangroves from north-eastern Brazil. Earth Surf. Process. Landforms, 45: 375392.

Coleman, J.M, \& Gagliano, S.M. (1995): Cyclic sedimentation inthe Mississipi river deltaic plain. Gulf Coast Assoc. Geol. Socs. Trans.; 14: 67-80.

CPRM - Companhia de Pesquisa de Recursos Minerais (2017): Geobank - Geologia Folha Itapetinga (SD.24-Y-D) 2006. Available in: http://geosgb.cprm.gov.br/.

Dominguez, J.L.; Bittencourt, A.S.; Santos, A.N.; Andrade, A.C.S.; Lavenere-Wanderley, O.A.A.O.; Silva, I.R.; Queiroz, I.G.; Freitas, L.B.; Nascimento, L.; Silva, R.P. (2017): Erosão e Progradação do Litoral Brasileiro - Bahia. Ministério do Meio Ambiente. 2012. Available at https://www.mma.gov.br/publicacoes/gestaoterritorial/category/80-gestao-costeira-g-erosao-e-progradacao.

Empresa Brasileira de Pesquisa Agropecuária - EMBRAPA (1997): Manual de métodos de análise de solo. 2. ed. Rio de Janeiro, Centro Nacional de Pesquisa de Solos, $212 p$.

Folk, R.L.; Ward, W.C. (1957): Brazos River bar: a study in the significance of grain size parameters. Journal of Sedimentary Petrology, 27: 3-26. 
Fontes, N.A.; Moraes, C.A.; Cohen, M.C.L.; Alves, I.C.C, França, M.C.; Pessenda, L.C. R.; Francisquini, M.I.; Bendassolli, J.A.; Macario, K. (2017): The Impacts of the Middle Holocene High Sea-Level Stand and Climatic Changes on Mangroves of the Jucuruçu River, Southern Bahia - North-eastern Brazil. Radiocarbon, 59 (1): 215-230.

Geoambientais (2011): Disponível em: www.sei.ba.gov.br: Geomorfologia: conceitos e tecnologias atuais. Oficina de Textos, São Paulo, SP, 2008, p. 56-93.

Goudie, A. (2006): Encyclopaedia of Geomorphology. London: Springer, 2: 1156.

IBGE - Fundação Instituto Brasileiro de Geografia e Estatística (2015): Diagnóstico ambiental da bacia do rio Jequitinhonha: diretrizes gerais para a ordenação territorial. Departamento de Recursos Naturais,

Karr J.R.; Chu E.W. (2000): Introduction: Sustaining living rivers. In: Jungwirth M.; Muhar S.; Schmutz S. (eds) Assessing the Ecological Integrity of Running Waters. Developments in Hydrobiology, vol 149. Springer, Dordrecht. https://doi.org/10.1007/978-94-011-4164-2_1

Lorente, F.L.; Castro, D.F.; Francisquini, M.I.; Pessenda, L.C.R. Fontes, N.A.; Cohen, M. C.L.; Bendassolli, J.A. Piccolo, M.C.; Macario, K. (2020): An integrated analysis of palynofacies and diatoms in the Jucuruçu River valley, north-eastern Brazil: Holocene paleoenvironmental changes. Journal of South American Earth Sciences, 103:102731.

Martin, L.; Dominguez, J.M.L.; Abilio C.S.P.; Bittencourt, A.C.S.P. (2003): Fluctuating Holocene Sea Levels in Eastern and South-eastern Brazil: Evidence from Multiple Fossil and Geometric Indicators. Journal of Coastal Research, 19 (1): 101-124.

Martin, L.; Suguio, K.; Flexor, J.M. (1993): As flutuações de nível do mar durante o quaternário superior e a evolução geológica de "deltas" brasileiros. Boletim IGUSP, Publicação especial, n.15, 184p.

Martins, L.R. (2003): Recent Sediments and Grain-Size Analysis. Gravel, 1: 90-105.

Martins, S E.M.; França, M.C.; Seddique, A.A.; Sial, A.N.; Pessenda, L.C.R.; Camargo, P.B.; Valença. L.M.M.; Santos, L.R.O.C.; Barcellos, R.L. (2020): Holocene vegetation changes according to sea-level and climate dynamics on tidal flats of the Formoso River estuary, north-eastern Brazil. Quaternary International, In Press.

Nascimento L.; Bittencourt, A,N,S.; Santos, A.N.; Dominguez, J.M.L. (2007): Deriva litorânea ao longo da Costa do Cacau, Bahia: Repercussões em geomorfologia costeira. Revista Pesquisa em Geociências. 34 (2): 45-56.

Nikolic, G.; Spalevic, V.; Curovic, M.; Khaledi Darvishan, A.; Skataric, G.; Pajic, M.; Kavian, A.; \& Tanaskovik, V. (2018): Variability of Soil Erosion Intensity Due to Vegetation Cover Changes: Case Study of Orahovacka Rijeka, Montenegro. Notulae Botanicae Horti Agrobotanici Cluj-Napoca, 47(1): 237-248.

Perez Filho, A.; Rubira, F. G. (2019): Evolutionary interpretation of Holocene landscapes in eastern Brazil by optimally stimulated luminescence: Surface coverings and climatic pulsations. Catena, 172: 866-876.

Rocha, T.B.; Vasconcelos, S.C.; Pereira, T.G.; Fernandez, G.B. (2019): Datação por luminescência opticamente estimulada (LOE) nas cristas de praia do delta do rio Paraíba do Sul (RJ): considerações sobre a evolução geomorfológica entre o Pleistoceno Superior e o Holoceno. Revista brasileira de geomorfologia, 20 (3): 563-580.

Rossetti, D. F. Ambientes Costeiros. in: Florenzano, T. G. (org.).

Rull, V.; Vegas-Vilarubia, T.; Espinoza, N. P. (1999): Palynological record of an earlymid Holocene mangrove in eastern Venezuela: Implications for sea-level rise and disturbance history. Journal of Coastal Research, 15: 496-504. 
Sallun, A.E.M.; Suguio, K.; Tatumi, S.H.; Yee, M.; Santos, J.; Barreto, A.M.F. (2007): Datação absoluta de depósitos quaternários brasileiros por luminescência. Revista Brasileira de Geociências, 37 (2): 402-413.

Santana, D.B.; Bolleli, T.M.; Lense, G.H.E.; Silva, L.F.P.M.; Sestras, P.; Spalevic, V.; Mincato, R.L. (2021): Estimate of water erosion in coffee growing areas in Serra da Mantiqueira, Minas Gerais State, Brazil. Agriculture and Forestry, 67 (2): 75 88.

Scott, A.J.; Fisher, W.L. (1969): Delta system and deltaic deposition. Discussion notes. Austin, Department of Geological Sciences, Bureau of Economic Geology, University of Texas, p. 212.

Scruton, P.C. (1960): Delta building and the deltaic sequence. In: Shepard, F.P.; Phleger, F.B. e van Aandel, T.H. (Eds.). Recent Sediments, Northwest Gulf of Mexico. American Association of Petroleum Geologists, p. 82-102.

SEI - Superintendência de Estudos Econômicos e Sociais da Bahia (2004): Informações SEI.

SEI - Superintendência de Estudos Econômicos e Sociais da Bahia (2004): Mapas digitalizados do Estado da Bahia: base de dados. Salvador: SEI, (CD-ROM).

Silva, V. A. Geomorfologia antropogênica: mudanças no padrão de drenagem do canal principal e delta, no baixo curso da bacia hidrográfica do rio Jequitinhonha/BA. 209p. Tese de doutorado (Doutorado em Geografia) Departamento de Geografia do Instituto de Geociências da Universidade Estadual de Campinas, 209p.

Spalevic, V.; Djurovic, N.; Mijovic, S.; Vukelic-Sutoska, M.; Curovic, M. (2013): Soil Erosion Intensity and Runoff on the Djuricka River Basin (North of Montenegro). Malaysian Journal of Soil Science, 17: 49-68.

Spalevic, V.; Barovic, G.; Vujacic, D.; Curovic, M.; Behzadfar, M.; Djurovic, N.; Dudic, B.; Billi, P. (2020): The Impact of Land Use Changes on Soil Erosion in the River Basin of Miocki Potok, Montenegro. Water 2020, 12: 2973.

Suguio, K. (2003): Geologia Sedimentar. 1. ed. São Paulo: Editora Edgard Blücher, 265p.

Suguio, K.; Martin, L.; Bittencourt, A.C.S.P.; Dominguez, J.M.L.; Flexor, J.M.; Azevedo, A.E.G. (1985): Flutuações do nível relativo do mar durante o Quaternário superior ao longo do litoral brasileiro e suas implicações na sedimentação costeira. Rev. Bras. Geoci. 15: 273- 286.

Tavares, A.S.; Uagoda, R.E.S.; Spalevic, V.; Mincato, R.L. (2021): Analysis of the erosion potential and sediment yield using the IntErO model in an experimental watershed dominated by karst in Brazil. Agriculture and Forestry, 67 (2): 153-162.

Tomazelli, L.J. (1990): Contribuição ao estudo dos sistemas deposicionais holocênicos do nordeste da província costeira do Rio Grande do Sul, com ênfase no sistema eólico. Universidade Federal do Rio Grande do Sul, (Tese de Doutorado), Porto Alegre. 201p.

Willett, S.D.; McCoy, S.W.; Perron, J.T.; Goren, L. Chen, C.Y. (2014): Dynamic Reorganization of River Basins. Science, 2014 Mar 7; 343(6175): 1248765. doi: $10.1126 /$ science. 1248765

Wintle, A.G.; Murray, A.S. (2000): Luminescence dating of quartz using an improved single-aliquot regenerative-dose protocol. Rations Measurements. 32 (1): 57-73.

Wintle, A.G.; Murray, A.S. (2006): A review of quartz optically stimulated luminescence characteristics and their relevance in single-aliquot regeneration dating protocols. Rations Measurements, 41 (1): 369-391.

Wright, L.D. (1978): River deltas. in: Davis, R. A. (editor). Coastal sedimentar environments. Nova York: Springer - Verlag, p. 5-68. 